\section{The deadweight cost of war: An illustrative CGE}

John Gilbert, Krit Linananda, Tanigawa Takahiko, Edward Tower, and Alongkorn Tuncharoenlarp

War has several causes. Dictators and others such, to whom war offers, in expectation at least, a pleasurable excitement, find it easy to work on the natural bellicosity of their peoples. But, over and above this, facilitating their task of fanning the popular flame, are the economic causes of war, namely, the pressure of population and the competitive struggle for markets. It is the second factor, which probably played a predominant part in the nineteenth century, and might again, that is germane to this discussion.

[T] here was no means open to a government whereby to mitigate economic distress at home except through the competitive struggle for markets. For all measures helpful to a state of chronic or intermittent under-employment were ruled out, except measures to improve the balance of trade on income account.

Thus, whilst economists were accustomed to applaud the prevailing international system as furnishing the fruits of the international division of labour and harmonising at the same time the interests of different nations, there lay concealed a less benign influence; and those statesmen were moved by common sense and a correct apprehension of the true course of events, who believed that if a rich, old country were to neglect the struggle for markets its prosperity would droop and fail. But if nations can learn to provide themselves with full employment by their domestic policy (and, we must add, if they can also attain equilibrium in the trend of their population), there need be no important economic forces calculated to set the interest of one country against that of its neighbours.

- John Maynard Keynes. 1936. The General Theory of Employment, Interest and Money. London, U.K.:Palgrave-Macmillan. [Extract from chapter 24.]

$\mathrm{W}$ ar is costly both because of the resources used up and because of the inefficiency introduced by the higher current or deferred taxes necessary to finance it. War has been justified by its ability to help an economy achieve full employment. As Keynes points out and as Leontief, et al. (1965) demonstrate with a simulation, war is far from a first-best policy for doing so. Historically, employment has been relatively high in times of war. So as a matter of history, does war put wasted resources to work? Barro (2008) argues that the higher employment that war brings reflects higher labor force participation created by the need to smooth consumption, and maintain the standard of living when resources are being sucked up by the military. The hunger for consumption at times when war has created scarcity causes folks to try to borrow more, which pushes up interest rates. This high reward attached to earning and saving for the future further encourages work. In his view war does not reflect putting previously wasted resources to work.

This article describes the simulations of an intertemporal computable general equilibrium (CGE) model, which illustrates that the cost of war depends on how it is financed, and that the increase in employment that it generates may be explained by the logic that Barro offers. Our model can be loaded into GAMS, a program which is available free of charge online, so readers themselves can simulate variations on the model.

The model was developed by an undergraduate class in computer modeling at Chulalongkorn University, Bangkok, Thailand. It was designed to provide a simple application of computable general equilibrium modeling, and to illustrate the excess burden of government expenditure under alternative assumptions about the economy and the form that taxation takes. We have chosen to tell a story where that expenditure is war, but the ideas apply to any sort of government expenditure.

\section{The model}

The conceptual structure of the model is best captured by enumerating the series of steps it follows. Appendix A contains the computer code.

1. We assume that the world exists for three periods.

2. There is only one good. "Widgets" are produced at home and abroad.

3. All citizens are identical, with identical productivity and identical tastes in consumption of goods and leisure throughout the entire three periods. Thus, we can model the economy as if there was only one individual. We call her the representative citizen. Flexible wages keep our representative citizen employed to the extent she wishes to be.

4. Our representative citizen has Cobb-Douglas preferences in work and leisure over 
the three periods.

5. The exponents attached to work and leisure in each of the periods are identical and sum to one. This means that an $\mathrm{N}$ percent increase in consumption of goods and leisure in all periods causes an $\mathrm{N}$ percent increase in utility, for any N. Of course our individual's endowment of time is fixed, so such an expansion is not possible. A hypothetical outward shift in the budget constraint by $\mathrm{N}$ percent also increases her utility by $\mathrm{N}$ percent. Since the endowment of leisure is fixed, and the exponents of the Cobb-Douglas utility function on goods and leisure each period are equal, a one percent increase in widget consumption each year over the entire lifetime, holding leisure consumption constant, would increase utility by only half a percent, so from increasing goods consumption alone, holding leisure constant, there is diminishing marginal utility.

6. Our individual equates the present value of her disposable income over the three periods of her life to the present value of her consumption. This is to say, she exhausts her savings at the end of her life.

7. The government equates the present value of its spending to the present value of taxes collected. This is to say, the government runs a balanced budget over the lifetime of the model.

8. In the variants of the model when we permit capital flows, arbitrage, and perfect foresight, we keep the domestic real interest rate equal to the foreign one. In our other simulations, where there is no international investment, the interest rate equates domestic saving to zero each period, because the economy as a whole cannot save.

9. Labor is the only factor of production, and its marginal physical product is one widget per day.

10. The interest rate is expressed in real terms. We assume that nobody holds money, because the expected rate of inflation is so high that bonds are a better store of value.

11. There is no investment in the national accounts sense, just consumption and government expenditure and in the open economy, imports and exports.

The simulations

The simulations are arranged from best situation to worst situation. The move from each simulation to the next involves tweaking the model in one respect. This helps us see what drives the results.

Simulation 1: Peace

This is our benchmark simulation. We assume a closed economy. We solve the model to maximize the utility of the representative citizen, given the prices and endowments. She is endowed with 100 days of time each year. Peace reigns. The model solution is that she consumes 50 days of leisure and 50 widgets each year. The real interest rate in period 1 is the interest rate that applies to a bond issued in period 1 and redeemed in period 2. The real interest rate in period 2 is that which applies to a bond issued in period 2 and redeemed in period 3. From now on we will refer to the real interest rate simply as the interest rate. We have defined a unit of leisure and a widget so that the wage and the price are both one in all three periods. We define utility as a linearly homogenous Cobb-Douglas function and define the initial level of utility as the value of goods and leisure consumed. Under peace the interest rate is perpetually zero. So under peace the lifetime leisure endowment is tradable for 300 widgets. We can label one indifference curve arbitrarily. We define the citizen's level of utility in the peace equilibrium as the endowment that supports the indifference curve attained during our peaceful equilibrium. It is $2 * 50 * 3=300$ utils.

The model is calibrated (the parameters are selected) so the individual maximizes her utility by consuming in each period what she produces in each period when the interest rate is zero. Consequently, the interest rate settles at zero. In this model there is no preference for consumption in one period over another. The individual just wishes to produce and consume at constant rates. If the economy had been open with our individual able to borrow and lend internationally at a zero interest rate, the result would have been the same.

There are no taxes, because there is no government expenditure in this Eden of peace.

The story is told in the numbered column 1 of Table 1 (Appendix B; the notation is explained next to the table). Utility is 300 , output is 50 widgets per year. Leisure is 50 days per year. The government buys no goods in any period. 50 widgets are consumed in each period. The tax rates are zero. The interest rates are zero. Net exports in each period are zero.

Simulation 2: War in period 2 only; lump-sum taxes and an open economy

Now the economy fights a war in year 2. For this, it requires 40 widgets. The world interest rate is assumed to be zero. In period 1 , our representative citizen sees scarcity coming in year 2 . She wants to smooth consumption and work effort, so she saves in both year 1 and year 3 . This allows her to smooth out consumption, so consumption is identical in all three periods. It also allows her to smooth out work effort, so leisure is the same in all three years. The stabilizer is the international economy. The world interest rate is assumed to be zero. Thus our country has a trade surplus in year 1 and 3 and a trade deficit in year 2 . The interest rates are all zero, so the sum of the trade imbalances equals zero. Annual consumption, annual leisure and intertemporal utility all fall. In particular, the utility of our representative citizen falls from 300 utils in simulation 1 to 260 utils in simulation 2 . The reason is that war has taken away from her 40 of the 300 units of leisure with which she is endowed. Output and employment rise to generate the necessary output and employment needed for the war effort, but 
without raising the ratio of leisure consumption to goods consumption.

Simulation 3: Small war in period 2 only; optimum tax

In simulation 3, we have a small war, which uses only a single widget. The war occurs in period 2. It is financed with an excise tax on production in the three periods. The tax rate is chosen by GAMS to maximize utility. Utility is defined so that the marginal utility of a widget in the initial equilibrium is one. Utility falls from 300 utils to 299. (Actually the number produced by GAMS was 298.995 utils.) Thus the drop in utility is very close to the one widget worth of utility that is needed to prosecute the war. In the limit, as the war becomes tiny, the drop in utility approaches the resources used up to finance the war, in spite of the distortionary taxation. Thus, the cost of the distortionary taxation is only a second-order effect. The ratio of the excess burden of taxation to the cost of the resources used up in fighting the war approaches zero in the limit as the resources used up to fight the war approaches zero. Consequently, the cost of distortionary taxation becomes relevant only for large levels of taxation.

The war is anticipated in period 1 . Consequently, folks desire to save for the hard times ahead, pushing the period 1 interest rate to minus one percent. However, when the hard times hit in period 2, our citizens try to borrow to smooth consumption, pushing the period 2 interest rate to plus one percent. To the limits of accuracy of the program, consumption is smoothed to equality in each of the three periods. Output expands in the second "war" period. It contracts in the two "peace" periods. The cause of the expansion is the desire to maintain consumption. The cause of the two contractions is the higher taxation which discourages work.

This illustrates that one cannot assess the employment benefit of war by just comparing war periods with others. We see that period 2's war discouraged work effort in the other two periods.

This issue is present in the current U.S. American discussion of how increased spending can shrink spending by forcing higher taxes to finance it. Alan Blinder (2011) writes “OK. But the question remains: How can the government destroy jobs by either hiring people directly or buying things from private companies? ... One possible answer is that the taxes necessary to pay for the government spending destroy more jobs than the spending creates. That's a logical possibility, although it would require extremely inept choices of how to spend the money and how to raise the revenue.”

Simulation 4: War in period 2 only; lump-sum taxes and a closed economy

The innovation in this simulation is that international trade is not available to smooth consumption and leisure. In an attempt to smooth consumption, workers try to save in period 1 and borrow in period 2 . This makes the period 1 interest rate negative and the period 2 interest rate positive. In an attempt to raise consumption in period 2, our individual works harder in that period. Thus war increases employment. The increase, however, is a change in voluntary employment, not a reduction in Keynesian involuntary unemployment. Leisure falls back to its peaceful levels of 50 days in periods 1 and 3 .

Taxation has the same effect regardless of when it is levied. This is called Ricardian equivalence, after David Ricardo who enunciated the proposition, which was later revived by Barro, and named Ricardian equivalence by James Buchanan (1976). The tax rates are zero, for the taxes are lump-sum. In this economy, it does not matter when the government collects the lump-sum taxes.

We expected the negative interest rate in the first period to encourage postponement of work from the first to the second period, and the positive interest rate in the second period to encourage the acceleration of work effort from the third to the second period. That is the case compared with simulation 2 with the lump-sum taxation and an open economy. However, we see that leisure and consumption in the first and third periods remained at their peaceful levels of 50 .

Utility drops below that of simulation 2. The drop is to 253.03 utils from 260 utils. This demonstrates the cost of autarky, when there is war in one period. More generally it demonstrates the cost of autarky when government spending makes variable demands on the economy. Steady work becomes unsteady work.

Simulation 5: War in period 2 only; an optimal intertemporal VAT and a closed economy

The innovation in this simulation as compared with simulation 4 is that lump-sum taxes are no longer available. Taxes are imposed to fight the war in all three periods. The mix of tax rates is optimized. The marginal welfare cost of tax collection rises with the tax rate in any period, so optimal taxation involves spreading the tax burden over the three periods. Leisure expands in each period and consumption falls in each period as compared to simulation 4 . This is due to the disincentive effects of taxation. The tax rate is highest in the war period and at a lower level in the other two periods. This demonstrates that uniform taxation is an inferior solution.

Utility drops below that of simulation 4. It falls from 253.03 utils to 246.974 utils, demonstrating that lump-sum taxation beats uniform taxation.

Simulation 6: War in period 2 only; uniform VAT and a closed economy

The innovation in this simulation is that a uniform VAT is required to fight the war. The tax rate is the same in each period. Utility drops below that of simulation 5 . The drop is a relatively small amount, from 246.974 utils to 246.703 utils. Still, it does demonstrate the superiority of optimal intertemporal taxation to uniform intertemporal taxation. 


\section{Simulation 7: War in period 2 only; an unanticipated war and a closed economy}

The innovation in this simulation is that the war is unanticipated. So no financial war chest is built-up prior to the war. Consequently, the war must be financed with VAT taxes collected in periods 2 and 3. Utility drops below that of simulation 6 . The drop is from 246.703 utils to 243.288 utils. The economy behaves in period 1 as it does with universal peace. But in periods 2 and 3 work and consumption fall below the levels when war is anticipated in simulation 6.

Simulation 8: War in period 2 only; VAT, a balanced budget, and a closed economy

The innovation in this simulation is that the budget must be balanced in each period. Perhaps the government does not anticipate the war and its credit rating is so bad that it cannot partially finance the war with revenues anticipated to occur in period 3. Thus, the impact of the very high taxes, just in period 2, is to dramatically reduce the incentive to produce in that period and to dramatically reduce utility. This is the worst financing option. The fall in consumption from 20 widgets to 10 widgets in period 2 is particularly dramatic. Utility falls from simulation 7's level of 243.288 utils to 229.417 utils.

Simulation 9: Perpetual war; an optimal intertemporal VAT and a closed economy

The innovation here is that the war is perpetual, and anticipated. Forty widgets are required to fight the war each period. Since the war requires the same resources each period, there is no incentive for the private sector to borrow or lend. Utility for obvious reasons falls below that in any of the other simulations. The interest rate stays at its peacetime level of zero. The tax rate rises to a uniform level of 400 percent. Utility drops to its lowest level. Consumption, output, and the tax rate are constant in all three years. This illustrates Barro's point that a permanent increase in government expenditure does not push up interest rates. The higher tax rates increase the ratio of leisure to goods consumed. Since the utility function is Cobb Douglas, the share of the endowment of leisure spent on leisure stays constant at the same level as in peacetime.

How big is the marginal welfare cost of taxation?

Our simulations are simply numerical examples. How important is the marginal welfare cost (MWC) of taxation in practice?

The MWC is the incremental welfare change over the additional tax collected as the tax rises. Empirically, the MWC can be quite high. Charles Stuart (1984) estimates that for labor income in the United States it is 24 percent of the tax collected. Ballard, et al. (1982) estimate it to be 79 percent for the U.S., as quoted in Shoven and Walley
(1984). We asked two leading practitioners of tax reform in less developed countries They estimated 30 percent and 50 percent for the kinds of tax changes that are likely to occur in less developed countries. Also see Judd (1987), who finds very high MWC's for the taxation of capital. There are efficiency costs associated with collecting taxes which exceed those based on just looking at the tax wedge. These real-world issues consist of administrative costs of tax collection; resources used up in tax avoidance, tax compliance, and tax evasion as well as resource misallocation costs. We have not considered these in the simulations.

Warlters and Auriol (2007) provide estimates of the marginal welfare cost of tax collection for 38 African countries. The ranges for the taxation of capital are 103 percent to 7 percent; for the taxation of labor: 101 percent to 5 percent; for exports: 214 percent to 2 percent; and for imports: 23 percent to 0 percent. The figures vary considerably, depending on the country and on the type of tax. In some cases, taxes are already over the maximum revenue level. The authors also provide a useful survey of estimates by other investigators.

As the tax rate rises, taxes collected typically reach a maximum and then decline. As the rate approaches the maximum, the MWC approaches infinity. It is at this point that the MWC approaches infinity, or what is the same idea, that the Laffer curve hits its maximum.

There are of course some taxes which are desirable from a Pigovian standpoint, such as taxes on pollution and congestion. However, one runs out of these after a while. So, in general, we expect the marginal welfare cost of tax collection to rise with the amount of tax collected. Thus, if demands on the treasury increase for reasons other than war, the incentive should be to scale back all spending including that on war.

\section{Conclusion}

We have built a simple model to demonstrate that the cost of war depends on how it is financed. The tax distortion should be reckoned as part of war's cost. When budgets are already constrained by other fiscal issues, the cost of war is higher than it would have been otherwise.

A second issue is that higher taxation discourages work. So one cannot assess the employment benefit of war by just comparing war periods with others, for those other periods may suffer from the hangover of taxes needed to pay down war debt.

\section{Notes}

John Gilbert is Professor of Economics at Utah State University, Logan, UT, USA. He may be reached at<jgilbert@usu.edu>. Tanigawa Takahiko is earning his bachelor's degree in the Faculty of Economics, Saitama University, Japan. He may be reached at<s07ee172@mail.saitama-u.ac.jp>. Krit Linananda is earning his 
economics bachelor of arts degree at Chulalongkorn University, Bangkok, Thailand, and may be reached at <PEC_vc80@hotmail.com>. Ed Tower, the corresponding author, is Professor of Economics at Duke University, Durham, NC, USA, and Visiting Professor of Economics at Chulalongkorn University, Bangkok, Thailand. He may be reached at< tower@econ.duke.edu>. Alongkorn Tuncharoenlarp earned his economics bachelor of arts degree at Chulalongkorn University, Bangkok, Thailand. He can be reached at <g_9_pd@hotmail.com $>$. We are grateful to the editors for guidance and to Conrad Chou and Thomya Wongcharoen for comments.

\section{References}

Ballard, C., J.B. Shoven, and J. Whalley. 1982. “The Welfare Costs of Distortions in the U.S. Tax System: A General Equilibrium Approach.” Cambridge, MA: National Bureau of Economic Research Working Paper no. 1043 (December).

Barro, R. 2008. Macroeconomics: A Modern Approach. Mason, OH: Thompson South-Western.

Blinder, A. 2011. “The GOP Myth of Job-Killing Spending.” The Wall Street Journal. 21 June 2011. http://online.wsj.com/article/SB100014240527023036356045 76392023187860688.html

Buchanan, J.M. 1976. "Perceived Wealth in Bonds and Social Security: A Comment." Journal of Political Economy. Vol. 84, No. 2, pp.337-342.

Judd, K.L. 1987. "The Welfare Cost of Factor Taxation in a Perfect-Foresight Model.” Journal of Political Economy. Vol. 95, No.4, pp. 675-709.

Leontief, W.W., A. Morgan, D. Simpson, K. Polenske, and E. Tower. 1965. "The Economic Impact-Industrial and Regional-of an Arms Cut.” Review of Economics and Statistics. Vol. 47, No 3, pp. 217-241.

Shoven, J.B. and J. Whalley. 1984. "Applied General-Equilibrium Models of Taxation and International Trade: An Introduction and Survey." Journal of Economic Literature. Vol. 22, No. 3, pp. 1007-1051.

Stuart, C. 1984. "Welfare Costs of Additional Tax Revenue in the United States." American Economic Review. Vol. 74, No. 2, pp. 352-362.

Warlters, M. and E. Auriol. 2007. "The Marginal Cost of Public Funds in Developing Countries: An Application to 38 African Countries.” The World Bank. 3 October 2007. http://idei.fr/doc/wp/2007/marginal_cost.pdf.

Appendix A: The GAMS Code for the Model

* One can download GAMS from the GAMS home page. Then copy this code into the project directory. *Then press "Run."

* This problem describes a government which wages a war in one to three periods.

* Its representative citizen has a Cobb Douglas utility function in consumption

* in the three periods and leisure in the three periods.

* All variables are in per capita terms. We normalize the wage

* rate to equal 1 in each periods. One unit of leisure can be converted into one
* unit of the good. i.e. the marginal physical product of labor is 1. Each citizen is endowed with * one hundred units of labor each period. This means that the sum of consumption, government

* expenditure on war, net exports, and leisure equals 100 each period. The problem is to find

* leisure in the three periods and the interest rate in each of the two periods and

* consumption in each of the three periods. There are 18 variables and between 15

* and 18 equations depending on the model. In all models, there are no more equations than variables.

* In some models there are fewer equations than variables, because some variables

* can be set optimally.

* This means we have two degrees of freedom. Thus we can set tax rates arbitrarily

* in two periods recognizing that the tax rate in the third period must be

* that which causes the present value of government expenditure to equal the present

* value of taxes collected.

variables u,c1,c2,c3,g1,g2,g3,leisure1,leisure2,leisure3,r1,r2,t1,t2,t3,x1,x2,x3;

equations

e1,e2,e3,e4,e5,e6,e7,e8,e9,e10,e11,e12,e12A,e13,e14,e15,e16,e17,e18,e19,e20,e21,e22,e23,e24,e25,e2 $6, \mathrm{e} 27, \mathrm{e} 28, \mathrm{e} 29, \mathrm{e} 30, \mathrm{e} 31 ;$

e1..u $=\mathrm{e}=6{ }^{*} \mathrm{c} 1^{* *} 0.16666667{ }^{*} \mathrm{c} 2{ }^{* *} 0.16666667{ }^{*} \mathrm{c} 3^{* *} 0.16666667{ }^{*}$ leisure ${ }^{* *} 0.16666667{ }^{*}$ leisure2 ${ }^{* *} 0.16$ $666667 *$ leisure $3 * * 0.16666667$;

$* u$ is utility of the representative citizen. ci is consumption in period i. leisurei is leisure in period $i$.

* Leisure and consumption have identical weights in the utility function regardless of the period in which they occur.

e2..c $1+\mathrm{g} 1+\mathrm{x} 1+$ leisure $1=\mathrm{e}=100$;

e3..c $2+\mathrm{g} 2+\mathrm{x} 2+$ leisure $2=\mathrm{e}=100$;

e4..c $3+g 3+x 3+$ leisure $3=\mathrm{e}=100$;

* gi is government purchases of widgets in period $i$. xi is net exports of widgets in period $i$.

* Labor endowment is 100 each period. It can be converted into widgets. The output

* of widgets equals consumption plus government purchase plus net exports.

* Thus equations 2,3,and 4 are a production possibility frontier combined with the * national income identity.

e5..c2 $=\mathrm{e}=\mathrm{c} 1 *(1+\mathrm{r} 1)$;

* ti is the advalorem tax rate in period $\mathrm{i}$, expressed as a proportion of the price to the producer.

* $\mathrm{r} 1$ is the real interest rate between period 1 and period 2 .

* r2 is the real interest rate between period 2 and period 3 .

$\mathrm{e} 6 . . \mathrm{c} 3=\mathrm{e}=\mathrm{c} 2 *(1+\mathrm{r} 2)$

* Equation 5 eqauates the ratio of of the marginal utilities of widgets in

* period 1 and 2 to the relative price of widgets in periods 1 and 2 .

* Equation 6 does the same for periods 2 and 3.

e7..g1 $=\mathrm{e}=0$;

e8..g2 $=\mathrm{e}=0$;

e9..g3 $=e=0$;

e10..g2=e=1;

e11..g1 $=\mathrm{e}=40$;

e12..g2 $=\mathrm{e}=40$;

e12A..g2 $=\mathrm{e}=10$;

e12A..g2 $=\mathrm{e}=10$

e13..g3 $=\mathrm{e}=40$

* Equations 7 through 13 describe the extent to which the government is purchasing

* widgets in order to fight a war.

e14..leisure $1=\mathrm{e}=(1+\mathrm{t} 1) * \mathrm{c} 1$;

e15..leisure $2=\mathrm{e}=(1+\mathrm{t} 2) * \mathrm{c} 2$

e16. leisure $3=e=(1+3) * 3$

* Equations 14-16 equate the marginal utilities of widgets and leisure to the

* relative price of goods and leisure in each of the three periods.

e17..g1+g2/(1+r1)+g3/((1+r1)*(1+r2)) $=\mathrm{e}=\mathrm{t} 1 *(\mathrm{c} 1+\mathrm{g} 1) /(1+\mathrm{t} 1)+\mathrm{t} 2 *(\mathrm{c} 2+\mathrm{g} 2) /((1+\mathrm{t} 2) *(1+\mathrm{r} 1))+\mathrm{t} 3 *(\mathrm{c} 3+\mathrm{g} 3) /($ 


\section{$\left.(1+\mathrm{t} 3)^{*}(1+\mathrm{r} 1)^{*}(1+\mathrm{r} 2)\right)$}

* Equation 17 says that the present value of government spending must equal the

* present value of taxes collected. It is used when taxes are not lump sum.

$\mathrm{E} 18 . . \mathrm{x} 1+\mathrm{x} 2 /(1+\mathrm{r} 1)+\mathrm{x} 3 /((1+\mathrm{r} 1) *(1+\mathrm{r} 2))=\mathrm{e}=0$;

* equation 18 says that the present value of net exports must equal zero.

* It is used in the open economy simulations. It is the intertemporal balance of

* trade constraint.

E19..x1 $=\mathrm{e}=0$;

$\mathrm{e} 20 . . \mathrm{x} 2=\mathrm{e}=0$;

$\mathrm{e} 21 . . \mathrm{x} 3=\mathrm{e}=0$

* Equations 19-21 are used in the closed economy simulations.

$\mathrm{e} 22 . . \mathrm{r} 1=\mathrm{e}=0$;

$\mathrm{e} 23 . \mathrm{r} 2=\mathrm{e}=0$;

* The world real interest rates are zero. In the open economy simulations arbitrage also keeps the domestic real interest rates at zero.

$\mathrm{e} 24 . . \mathrm{t} 2=\mathrm{e}=\mathrm{t} 1$;

$\mathrm{e} 25 . \mathrm{t} 3=\mathrm{e}=\mathrm{t} 2$

$\mathrm{e} 26 . . \mathrm{t} 1=\mathrm{e}=0$;

$\mathrm{e} 27 . \mathrm{t} 3=\mathrm{e}=0$;

e28..leisure $1=\mathrm{E}=50$;

* These equations are used when there are constraints on the tax structure.

g1.L=0; g2.L=0; g3.L=0; c1.L=50; $c 2 . L=50 ; c 3 . L=50 ; r 1 . L=0 ; r 2 . L=0$; leisure1.L=50; leisure2.L=50; leisure3.L=50; $\mathrm{t} 1 . \mathrm{L}=0$; $\mathrm{t} 2 . \mathrm{L}=0$; $\mathrm{t} 3 . \mathrm{L}=0$;

model peace/e1,e2,e3,e4,e5,e6,e7,e8,e9, e14,e15,e16,e19,e20,e21/;

model war2LargeLumpSumTaxOpen/e1,e2,e3,e4,e5,e6,e7,e9, e12,e14,e15,e16,e18,e22,e23/;

model war2SmallOptimalTaxClosed/e1,e2,e3,e4,e5,e6,e7,e9,e10,e14,e15,e16,e17,e19,e20,e21/;

model war2LargeLumpSumTaxClosed/e1,e2,e3,e4,e5,e6,e7,e9,e12,e14,e15,e16,e19,e20,e21/;

model war2LargeOptimumTaxClosed/ e1,e2,e3,e4,e5,e6,e7,e9,e12,e14,e15,e16,e17,e18,e19,e20,e21/; model war2LargeUniformTaxClosed/e1,e2,e3,e4,e5,e6,e7,e9,e12,e14,e15,e16,e17,e19,e20,e21,e24,e25/; mo d e l w a r $2 \mathrm{~L}$ a r g e U n a n t i c i p a t e d M e d i u m T a x C l o s e d /e1,e2,e3,e4,e6,e7,e9,e12A,e14,e15,e16,e17,e19,e20,e21,e22,e25,e26,E28/;

mo d e l w a r $2 \mathrm{~L}$ a $\mathrm{r}$ g e U n a $\mathrm{n}$ t i c i p a t e d T a x C l o s e d /e1,e2,e3,e4,e6,e7,e9,e12,e14,e15,e16,e17,e19,e20,e21,e22,e25,e26,E28/;

$\mathrm{m}$ o d e l w a r 2 L a r g e B a l a n c e d B u d g e t C l o s e d /e1,e2,e3,e4,e5,e6,e7,e9,e12,e14,e15,e16,e17,e19,e20,e21,e26,e27/;

$\mathrm{mod}$ e l p e r p e t u a l W a r L a r g e O p t i m u m T a x C l o s e d/ e1,e2,e3,e4,e5,e6,e11,e12,e13,e14,e15,e16,e17,e19,e20,e21/;

option limcol $=0$;

solve peace using NLP maximizing $u$;

solve war2LargeLumpSumTaxOpen using NLP maximizing u;

solve war2SmallOptimalTaxClosed using NLP maximizing u;

solve war2LargeLumpSumTaxClosed using NLP maximizing u;

solve war2LargeOptimumTaxClosed using NLP maximizing u;

solve war2LargeUniformTaxClosed using NLP maximizing u;

solve peace using NLP maximizing u;

solve war2LargeUnanticipatedMediumTaxClosed using NLP maximizing u;

solve war2LargeUnanticipatedTaxClosed using NLP maximizing u;

solve war2LargeBalancedBudgetClosed using NLP maximizing u;

solve PerpetualWarLargeOptimumTaxClosed using NLP maximizing u; 


\begin{tabular}{|c|c|c|c|c|c|c|c|c|c|}
\hline Simulation & 1 & 2 & 3 & 4 & 5 & 6 & 7 & 8 & 9 \\
\hline & $\begin{array}{r}\text { Perpe tual } \\
\text { peace }\end{array}$ & $\begin{array}{r}\text { War in } \\
\text { pe riod } 2 \\
\text { on ly, be st } \\
\text { tax and } \\
\text { trade } \\
\text { regime }\end{array}$ & \begin{tabular}{|r|} 
Small warin \\
period 2 only. \\
Optimum tax. \\
For small wars \\
there is no \\
dead weight loss \\
of tax finance.
\end{tabular} & $\begin{array}{r}\text { War in period } \\
2 \text { only. Best } \\
\operatorname{tax}\end{array}$ & $\begin{array}{r}\text { Warin } \\
\text { period } 2 \\
\text { only. } 2 \mathrm{nd} \\
\text { best tax }\end{array}$ & $\begin{array}{r}\text { Warin } \\
\text { period } 2 \\
\text { only. } 3 r d \\
\text { be st tax }\end{array}$ & $\begin{array}{r}\text { War in } \\
\text { pe riod } 2 \\
\text { only. } 4 \text { th } \\
\text { best tax }\end{array}$ & $\begin{array}{r}\text { Warin } \\
\text { period } 2 \\
\text { only. } 5 \text { th } \\
\text { best tax }\end{array}$ & $\begin{array}{r}\text { Perpetual } \\
\text { war. } \\
\text { Optimum } \\
\text { tax. }\end{array}$ \\
\hline $\begin{array}{l}\text { Warin } \\
\text { period }\end{array}$ & nowar & 2 & 2 & 2 & 2 & 2 & 2 & 2 & $1,2,3$ \\
\hline economy & closed & open & closed & closed & closed & closed & close d & closed & closed \\
\hline taxes & none & lump sum & VAT & Iump sum & VAT & VAT & VAT & VAT & VAT \\
\hline $\begin{array}{r}\operatorname{tax} \\
\text { structu re }\end{array}$ & none & $\begin{array}{r}\text { No matter. } \\
\text { Ricardian } \\
\text { e quival ence } \\
\end{array}$ & op ti mum & \begin{tabular}{|r|} 
No matter. \\
Ricardian \\
equivalence.
\end{tabular} & optim um & uniform & $\begin{array}{r}\text { unantici- } \\
\text { pate d } \\
w a r\end{array}$ & $\begin{array}{r}\text { balanced } \\
\text { budget }\end{array}$ & optimum \\
\hline Period 1 & $\mathrm{P}$ & $\mathrm{P}$ & $\mathrm{P}$ & $\mathrm{P}$ & $P$ & $P$ & $P$ & $\mathrm{P}$ & $\mathrm{W}$ \\
\hline Period 2 & $\mathrm{P}$ & $\mathrm{W}$ & W & $\mathrm{W}$ & $\mathrm{W}$ & $\mathrm{w}$ & 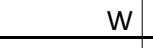 & $\mathrm{W}$ & $\mathrm{W}$ \\
\hline Period 3 & $\mathrm{P}$ & $\mathrm{P}$ & $\mathrm{P}$ & $\mathrm{P}$ & $\mathrm{P}$ & $\mathrm{P}$ & $\mathrm{P}$ & $\mathrm{P}$ & 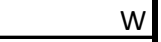 \\
\hline u tility & 300 & 260 & 299.00 & 253.03 & 246.97 & 246.70 & 243.29 & 229.42 & 134.16 \\
\hline$Y 1$ & 50 & 56.67 & 49.83 & 50 & 40.60 & 38.89 & 50 & 50 & 50 \\
\hline Y 2 & 50 & 56.67 & 50.33 & 70 & 62.02 & 63.33 & 60 & 50 & 50 \\
\hline Y 3 & 50 & 56.67 & 49.83 & 50 & 40.60 & 38.89 & 33.33 & 50 & 50 \\
\hline leisure 1 & 50 & 43.33 & 50.17 & 50 & 59.40 & 61.11 & 50 & 50 & 50 \\
\hline | eisure 2 & 50 & 43.33 & 49.67 & 30 & 37.98 & 36.67 & 40 & 50 & 50 \\
\hline leisure 3 & 50 & 43.33 & 50.17 & 50 & 59.40 & 61.11 & 66.67 & 50 & 50 \\
\hline $\mathrm{G} 1$ & 0 & 0 & 0 & 0 & 0 & 0 & 0 & 0 & 40 \\
\hline $\mathrm{G} 2$ & 0 & 40 & 1 & 40 & 40 & 40 & 40 & 40 & 40 \\
\hline G 3 & 0 & 0 & 0 & 0 & 0 & 0 & 0 & 0 & 40 \\
\hline C 1 & 50 & 43.33 & 49.83 & 50 & 40.60 & 38.89 & 50 & 50 & 10 \\
\hline$C 2$ & 50 & 43.33 & 49.83 & 30 & 22.02 & 23.33 & 20 & 10 & 10 \\
\hline C 3 & 50 & 43.33 & 49.83 & 50 & 40.60 & 38.89 & 33.33 & 50 & 10 \\
\hline $\mathrm{t} 1$ & 0 & 0 & 0.007 & 0 & 0.46 & 0.57 & 0 & 0 & 4 \\
\hline t2 & 0 & 0 & 0.007 & 0 & 0.73 & 0.57 & 1 & 4 & 4 \\
\hline t3 & 0 & 0 & 0.007 & 0 & 0.46 & 0.57 & 1 & 0 & 4 \\
\hline $\mathrm{r} 1$ & 0 & 0 & -0.01 & -0.4 & -0.46 & -0.40 & 0 & -0.8 & 0 \\
\hline$r 2$ & 0 & 0 & 0.01 & 0.667 & 0.84 & 0.67 & 0.67 & 4 & 0 \\
\hline $\mathrm{X} 1$ & 0 & 13.33 & 0 & 0 & 0 & 0 & 0 & 0 & 0 \\
\hline$\times 2$ & 0 & -26.67 & 0 & 0 & 0 & 0 & 0 & 0 & 0 \\
\hline $\mathrm{X3}$ & 0 & 13.33 & 0 & 0 & 0 & 0 & 0 & 0 & 0 \\
\hline
\end{tabular}

Notes: Yi is output in period I; Gi is war expenditure in period $\mathrm{I}$; $\mathrm{Ci}$ is consumption in period $\mathrm{I}$; ti is the tax rate in period $\mathrm{i}$ expressed as a fraction of the producer price;ri is the real interest rate on a loan in period I which matures in period I +1 (it is a proportion per period); $\mathrm{Xi}$ is the balance of trade in period $\mathrm{i}$ (this is exports minus imports). All national income flows are measured in widgets per period. 